\title{
A CLINICAL STUDY OF AMYLASE * IN THE URINE
}

WITH ESPECIAL REFERENCE TO THE PHENOLSULPHONEPHTHALEIN TEST $\dagger$

\author{
H. RAWLE GEYELIN, M.D. \\ NEW YORK
}

Since Majendie, ${ }^{1}$ in 1846 , first found an amylolytic enzyme in human blood, and later, in 1863 , Cohnheim ${ }^{2}$ wrote of its presence in the urine, Plósz and Tiegil, ${ }^{3}$ Foster, ${ }^{4}$ Iépine $^{5}$ and many other writers have confirmed these earlier investigators and attempted to determine the quantitative value of amylase with reference to certain pathological conditions, more particularly those of the kidney. All the various methods devised were unwieldy and inaccurate however, and most of the information gained contradictory. In 1908 Wohlgemuth $^{6}$ devised a quantitative test which for the simplicity, accuracy and uniformity of its results so far surpassed any test previously proposed that it has been generally adopted by chemists and clinicians alike for the estimation of amylase in blood, urine, feces and other body substances.

Nearly all the contributions to our literature on this subject have come from French and German writers, and in Germany particular attention has been directed to the quantitative estimation of amylase in blood and urine.

Wohlgemuth's original method devised for the quantitative estimation of amylase has been followed by numerous investigations into the experimental and clinical aspects of this ferment as found in the body fluids. The largest portion of this work has been done by Wohlgemuth and his pupils and has yielded very interesting results.

In order that we may have a clearer understanding of what is to follow, it seems advisable to give in detail the technic of Wohlgemuth's

* Throughout this paper the term amylase has been used in preference to the term diastase so generally employed by German writers, amylase having a more restricted significance than diastase; " $d$ " as a means of expressing the readings obtained is used simply in deference to the terminology employed in Wohlgemuth's original method.

$\uparrow$ From the Blumenthal Fellowship Foundation of the Medical Clinic, College of Physicians and Surgeons, Columbia University.

$\uparrow$ Submitted for publication, Aug. 1, 1913.

I. Wajendie: Compt, rend., Acad. d. sc., 1846, xxiii, 189.

2. Cohnheim: Virchow's Arch. f. path. anat., 1863, xxviii, 241.

3. PIosz and Tiegil: Arch. f. d. ges. Physiol. (Pflügers), 1873, vii, 391.

4. Foster, M.: Jour. Anat. and Physiol., 1867, i, 107.

5. Lépine: Compt. rend., Acad. d. se., 1891, cxiii, 1014.

6. Wohlgemuth, J.: Biochem. Ztschr., 1908, ix, 1. 
"starch-iodin" method for the quantitative estimation of amylase as outlined in his most recent publication on this subject. ${ }^{7}$ This differs in a few detrils only from his original method, which may be found in any text-book on physiological chemistry.

\section{TECHNIC}

Ten test-tubes numbered $1,2,3,4,5,6,7,8,9,10$ are placed in a test-tube stand (these tubes must be thoroughly cleansed, rinsed in distilled water and carefully dried). To each tube is added 1 c.c. of a normal saline solution from a graduated pipet (except in Tube 1, which contains 1 c.c. of the fluid to be tested). With a 1 c.c. pipet, accurately graduated into 0.1 c.c., draw up 1 c.c. of fluid to be tested and add to Tube 2, thoroughly mixing the fluids by three times drawing up the mixture of normal saline solution and test fluid and again expelling contents into the tube. Then finally draw up 1 c.c. of the fluid now diluted 1 to 2 and place this in Tube 3 , repeating the same process of mixing and again withdrawing 1 c.c. of mixture. This is to be repeated in all the succeeding tubes and in the last tube the 1 c.c. withdrawn can be discarded. This will give the following amounts of fluid to be tested in each tube (seven tubes suffice in most cases).

No. $1=1.0$ c.c.; No. $2=0.5$ c.c.; No. $3=0.25$ c.c. $;$ No. $4=0.125$ c.c.; No. $5=0.0625$ c.c.; No. $6=0.032$ c.c.; No. $7=0.016$ c.c.; No. $8=0.008$ c.c.; No. 9 $=0.004$ c.c.; No. $10=0.002$ c.c.

Now to each tube are added 2 c.c. of 0.1 per cent. starch solution (Kahlbaum's soluble starch), the tubes fitted into a wire cage after shaking gently, the cage placed on a water-bath at $38 \mathrm{C}$. for half an hour. The temperature should be very carefully watched, should be kept within one-half degree of $38 \mathrm{C}$, and the time aceurately measured. At the end of this time all tubes are withdrawn and placed in ice-water for five minutes to inhibit further amylolytic activity and are then replaced in test-tube stand. To each tube is then added 2 drops of fiftieth-normal iodin solution which must be freshly prepared from a stock solution of tenthnormal strength daily. ${ }^{8}$ One-to-one-thousand starch solution should be freshly prepared every three days and kept in refrigerator.

READING

If the urine is normal the first two or three tubes will be golden yellow in color, all starch having been digested, while the fourth will be reddish with no tinge of blue, the fifth violet and the others blue. ${ }^{9}$ The tube from which the reading is taken is the deep-red tube; this tube shows that all starch has been digested at least to the dextrin stage.

7. Wohlegmuth, J., and Noguchi, Y.: Berl. klin. Wchnschr., 1912, xxiii, 1069.

8. In case 2 drops of iodin solution to each tube is not sufficient to bring out a permanent color, add as many more drops to the tube as will be necessary, being careful to add exactly the same number of drops to each of the other tubes.

9. The various gradations in color as given above are not always the same; in fact it may be difficult to determine in some instances which tube constitutes the end-point or reaction tube but after some practice, the eye becomes trained to recognize that tube which no longer contains a bluish tint. Corbett (Quart. Jour. Med., 1913, vi, 351) in a very recent publication emphasizes the "mauve tube" as the "limit" tube and calculates from the tube preceding this, (the one with a "reddish-yellow color.") Wohlgemuth (see Note 7) defines the end point as follows: "Dasjenige Gläschen, in welchem der erste blaue Farbenton auftritt, das also bei Zusatz von Jod rotblau wird, gilt als Grenze (Limes) der Wiksamkeit und aus der in dem vorhergehenden Gläschen enthaltenen Serummerge wird die Fermentstärke berechnet." 
The calculation is then made as follows: In Tube 4 there was 0.125 c.c. urine or fluid which digested 2 c.c. of a 0.1 per cent. starch solution in half an hour at $38 \mathrm{C}$. Therefore 1 c.c. of fluid to be tested would digest starch according to the following equation:

$$
0.125: 2 \text { c.c. (starch) : : } 1 \text { c.c. }: \mathrm{X}=16
$$

One c.c. of fluid digested 16 c.c. of a 0.1 per cent. starch solution in half an hour; this Wohlgemuth designates as follows:

$$
\frac{38^{\circ}}{30^{\prime}}=16
$$

When twenty-four-hour digestion is employed he expresses it:

$$
\mathrm{D}-\frac{38^{\circ}}{24 \mathrm{hr} .} \mathrm{X} \text {. }
$$

The present work was undertaken with the object of determining two things: first, the clinical value of the estimation of amylase in the urine in determining the functionating powers of the kidney in various diseases, more particularly in renal and cardiac cases; second, the relationship between this test and another test of renal function, namely, the phenolsulphonephthalein test of Rowntree and Geraghty.

Most of the cases here reported fall under renal or cardiac headings, as these two conditions are the ones in which functional tests are most often made. But several other diseases have also been investigated with very interesting results. I had hoped also to make comparisons of the amylolytic value of the blood-serum synchronously with that of the urine, but, except in a few cases, this has not been possible, and will have to be taken up at some future date. In all cases investigated, samples of a twenty-four-hour specimen were used for reasons which will be explained later. ${ }^{10}$

The quantitative estimation of amylase in the urine as a test for the functional activity of the kidneys has been advanced by Wohlgemuth, ${ }^{11}$ Benczur, ${ }^{12}$ Wynhausen, ${ }^{13}$ Rosenthal, ${ }^{14}$ Marino, ${ }^{15}$ Corbett ${ }^{8}$ and Neuman. ${ }^{18}$ Wohlgemuth ${ }^{11}$ used it in conjunction with phloridzin, indigo-carmin and cryoscopy tests to determine unilateral disease of the kidney and found in a series of some fifty cases that it, with the freezing-point test, gave the most valuable results in estimating the relative functionating powers of the two kidneys. Wohlgemuth, ${ }^{7}$ Corbett, ${ }^{8}$ Neuman $^{18}$ and Rosenthal ${ }^{14}$ have shown that the amount of amylase in the urine of normal individuals

10. A few cubic centimeters of toluol should be added to all twenty-four-hour specimens, to prevent bacterial growth. This does not interfere with the " $d$ " readings, and preserves the urine for six months or more, giving the same " $d$ " reading at the end of that time as when freshly voided.

11. Wohlgemuth, J.: Ztschr. f. Urol., 1911, i, 801.

12. Benczur, J.: Wien. klin. Wehnschr., 1910, xxiv, 890.

13. Wynhausen, O. J.: Berl. klin. Wehnschr., 1910, xlvi, 2107.

14. Rosenthal, A.: Deutsch. med. Wehnschr., 1911, xxxvii, 923.

15. Marino, E.: Deutsch. Arch. f. klin. Med., 1911, ciii, 325.

16. Neuman: Deutsch. Arch. f. klin. Med., 1913, cix, 164. 
varied within very narrow limits, and for a given individual was almost constant, provided a twenty-four specimen was used. That there may be great variations in the amylolytic power of individual specimens of urine passed at certain times during the twenty-four hours, Wohlgemuth has shown as follows : ${ }^{1 \tau} 1$. There is more amylase in urine of fasting periods, that is, just before meals. 2. The amount begins to diminish after meals and gradually sinks until three or four hours after a meal, then gradually begins to rise again. This confirms the earlier investigations of Grützner, ${ }^{18}$ Gehrig, ${ }^{10}$ Hoffman, ${ }^{20}$ Rosenberg ${ }^{21}$ and Leo, ${ }^{22}$ who worked with cruder methods.

It has also been shown by Wohlgemuth ${ }^{23}$ by experiments on dogs that neither the kind nor amount of food taken has any effect on the quantity of amylase in the blood-serum. Schlesinger ${ }^{24}$ found the same for man, while Corbett ${ }^{8}$ concludes that in human beings the quantity of amylase in the twenty-four-hour urine does not vary even with marked dietary changes. He gives one instance, however, that of an infant aged 9 months, who had never had unaltered starch food before, and whose urine, after three days' administration of starch-containing food, showed an increase in amylolytic power amounting to almost five times as much as before the giving of starch. Neuman ${ }^{16}$ also concludes that changes in diet have no effect on the quantity of amylase in urine.

The influence ${ }^{\mathbf{1 7}}$ of sex on the amount of amylase in the urine shows that the urine of males has a slightly higher " $d$ " reading than that of females. This, however, is so small as to be negligible in clinical work.

According to Wohlgemuth, ${ }^{17}$ Corbett, ${ }^{8}$ Wynhauser ${ }^{13}$ and Marino, ${ }^{15}$ the reaction and salt concentration of the urine has no appreciable effect on the "d" readings. In this connection it may be mentioned that Cole, working with a pure (dialyzed) solution of ptyalin, shows that the effect of any electrolyte on the rate of action of the ferment is dependent on two factors - first, the acceleration due to anions other than hydroxylions, and second, the depression due to kations and hydroxylions.

Wohlgemuth ${ }^{26}$ himself, after careful studies of the salivary amylase, pancreatic amylase and the amylase of blood-serum, all of which he found to have the same properties, came to the following conclusions:

1. Sodium chlorid increases amylolytic action in twenty-four hours' digestion ten fold.

17. Wohlgemuth: Biochem. Ztschr., 1909, xxi, 432.

18. Grüttzner: Breslauer ärztl. Ztschr., 1882, xvii, 193.

19. Gehrig, J.: Arch. f. d. ges. Physiol. (Pflügers), 1885, xxxviii, 38.

20. Hoffman: Arch. f. d. ges. Physiol. (Pflügers), 1887, xli, 148.

21. Rosenberg: Dissertation, Tübingen, 1890 .

22. Leo: Verhandl. d. VII. Kongr. f. inn. Med., 1888, 364.

23. Wohlgemuth, J.: Biochem. Ztschr., 1909, xxi, 381.

24. Schlesinger, W.: Deutsch. med. Wchnschr., 1908, xiv, 593.

25. Cole: Jour. Physiol., 1904, xxx, 202.

26. Wohlgemuth, J.: Biochem. Ztschr., 1908, ix, 10. 
2. The lowest dilution in which sodium chlorid seemed to have an accelerating action was 0.002 to 0.00097 per cent.

3. The increased effect of sodium chlorid is due to the anion chlorid, therefore all other chlorid-containing neutral salts accelerate the enzyme.

4. Of the other halogen ions bromin also increases the action; also iodin, but to a less degree, while fluorin inhibits.

5. Alkalies, except sodium carbonate, inhibit the action of amylase and destroy it by prolonged action.

6. Neutral salts like sodium phosphate, oxalate and acetate inhibit the action of amylase, whereas the nitrate, nitrite and chlorate increase the action. Sodium sulphate is indifferent.

\%. Alanin and leucin inhibit, glycocol is indifferent.

8. Colloid metals (gold, silver, copper and iron), inhibit in proportionately smaller concentration, while in strong dilution they are indifferent and the addition of sodium chlorid does not alter their behavior.

As the amylase in urine is probably derived directly from that of the blood it must have the same properties as that of the blood. It can, therefore, readily be seen how difficult it would be to determine the individual factors concerned in the composite action of the various ions on the amylolytic power in such an ion complex as the urine. Of the urines I have studied, some two hundred in number, I have had only two, and both were from the same patient, which showed an alakine reaction; all the others were neutral or acid, the majority being acid. No appreciable effect on the " $\mathrm{d}$ " readings caused by reaction could be noted, except when decomposition was evident, this seeming to accelerate the action of amylase.

Other factors affecting action of the ferment in urine must here be mentioned. First, the action of blood. It has been shown ${ }^{27,}{ }^{28}$ that blood and various organ extracts have a marked accelerating action on the amylolytic activity of pancreatic juice, saliva, etc. So that urine containing blood will show a much higher amylolytic power than normal urine. Dudley Corbett, ${ }^{8}$ in a very recent publication has also demonstrated that the influence of blood on the amylolytic action of the urine is a strongly accelerating one. Neuman, ${ }^{16}$ however, states that in "several cases" during menstruation no effect could be noted. He does not state definitely, however, how much blood was present nor does he say whether the specimens examined were complete twenty-four-hour ones. Both these factors are important, particularly the former, as I have often centrifuged specimens of urine from menstruating women and in the sediment found only small numbers of red blood-cells, absolutely no macroscopic evidence of blood being present. It is only reasonable to

27. Wohlgemuth, J.: Biochem. Ztschr., 1911, xxxiii, 303.

28. Pozerski, L.: Thèse de Paris, 1902, 70. 
suppose that in these cases when such relatively minute quantities of blood were present, no, or very slight, alteration in the " $\mathrm{d}$ " value would be found.

Another factor which must be considered in regard to its effect on amylolytic activity in the urine is albumin. Very few authors have dealt with this at all. Lüthje ${ }^{29}$ found high amylase value in albuminous urines. Rosenthal ${ }^{14}$ found that the chronic interstitial forms of nephritis showed uniformly lower readings that did other forms, and generally less albumin is found in the chronic interstitial forms. He draws no deductions, however. Benczur concludes that high "d" readings are sometimes found in nephritics and other albuminuric conditions. He argues that his and Wohlgemuth's experiments ${ }^{30}$ in which they found increased " $d$ " value for blood-free kidney extracts of diabetic animals, show that the kidney plays some part in the production of urinary amylase, and further, that the inflammatory condition which produces albuminuria may also serve to stimulate the kidney cells to increased amylase production. Neuman ${ }^{16}$ denies any influence on the part of albumin or pus. Corbett, whose series of cases is small, gives this subject more detailed attention and theorizes as follows: The damage of kidney structure may be equally severe in cases with little or much albumin. The presence of much albumin is attributed to increased permeability of the kidney and the high "d" values so often obtained in these cases are due to the same factor. "For," he argues, "if the renal cells are permeable to the complex protein mixture, generally termed albumin, they should the more readily allow the passage of a simpler colloid, such as amylase." To support this theory he refers to cases of eclampsia with much albumin and many casts in which the "d" values were very high and in which there must have been severe damage to kidney structure. All the clinical evidence to date certainly points to higher " $d$ " values in those forms of nephritis with high albumin content of the urine than in those forms with little or no albumin which almost invariably give low readings for "d."

In stating the results in my own series of cases I have adopted a purely arbitrary method in comparing the amounts of albumin found in different cases; for instance, anything tabulated as trace or faint trace is designated as "little albumin," while anything from heavy trace to much albumin or a definite quantitative figure is designated as "much albumin."

On examination of the figures in Table 1 with reference to the influence of albumin on the " $\mathrm{d}$ " reading, thirty-four cases ${ }^{31}$ are found which have varying degrees of albuminuria; twelve cases which have

29. Lüthje, H.: Festschr. f. J. Rosenthal, 1906, ii, 131-138.

30. Wohlgemuth, J., and Benczur: Biochem. Ztschr., 1909, xxi, 460.

31. Case 29 is omitted as here the pus was very large in amount and was probably the main source of the albumin. 
TABLE 1.-Chronic INTERStitial Nephritis.

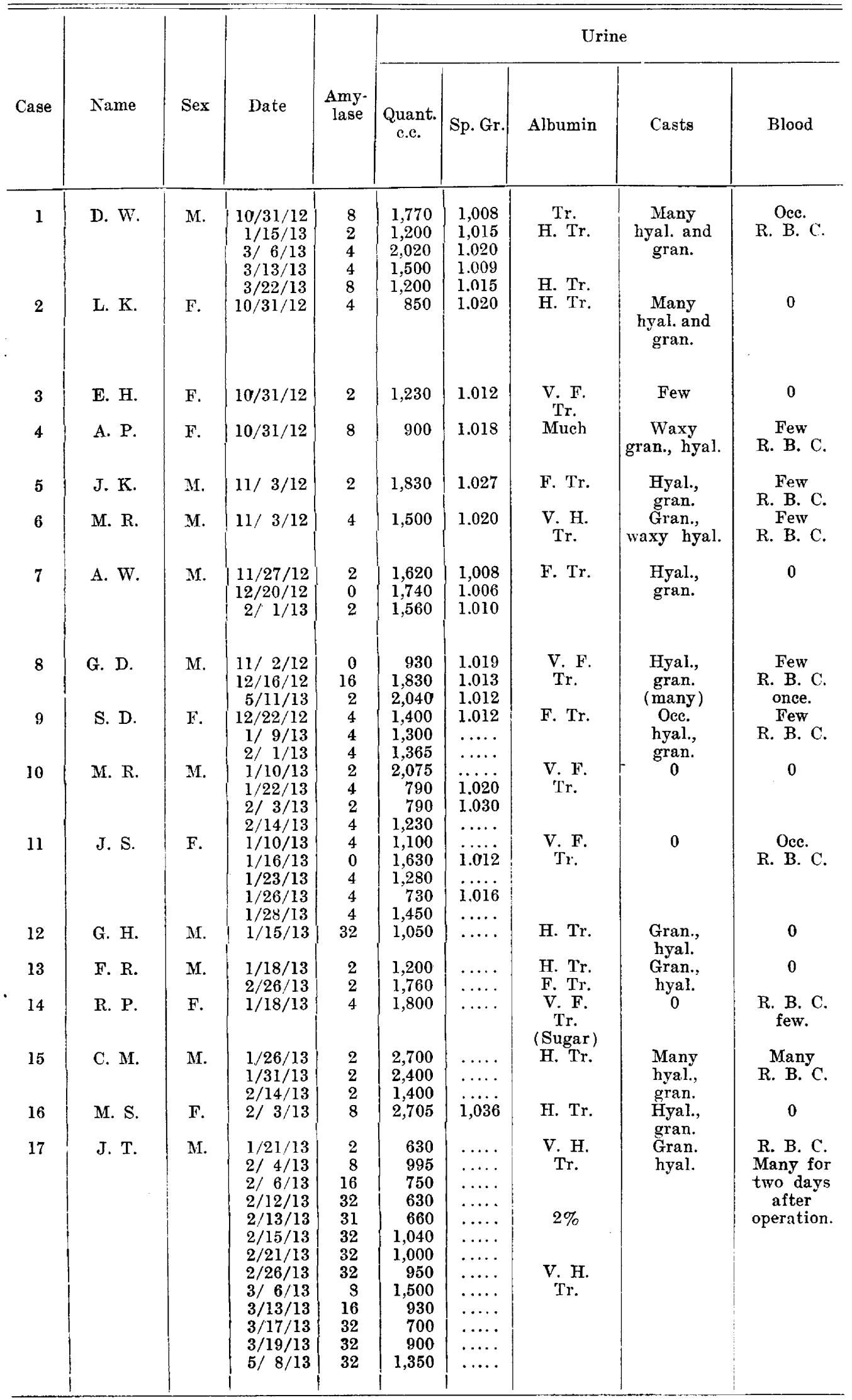




\begin{tabular}{|c|c|c|c|c|c|}
\hline \multicolumn{3}{|c|}{ Urine } & \multirow[b]{2}{*}{ Date } & \multirow[b]{2}{*}{ Disease } & \multirow[b]{2}{*}{ Result } \\
\hline $\begin{array}{l}\text { Blood } \\
\text { Pressure }\end{array}$ & Reaction & $\begin{array}{l}\text { Phenol- } \\
\text { sulphone- } \\
\text { phthalein } \\
\text { Per Cent. }\end{array}$ & & & \\
\hline $\begin{array}{l}240(S) \\
\text { to } \\
80(S) \\
(\text { term })\end{array}$ & Acid & $\begin{array}{l}55 \\
45 \\
56\end{array}$ & $\begin{array}{r}10 / 27 / 12 \\
11 / 13 / 12 \\
3 / 5 / 13\end{array}$ & Chronic interstitial nephritis. & Died \\
\hline $\begin{array}{l}170(\mathrm{~S}) \\
\text { to } \\
200(\mathrm{~S})\end{array}$ & Acid & 45 & $10 / 26 / 12$ & $\begin{array}{l}\text { Chronic interstitial nephritis. } \\
\text { This patient had hyperglyce- } \\
\text { mia and persistent glycosuria. } \\
\text { Regarded as a case of dys- } \\
\text { pituitarism. }\end{array}$ & Improved \\
\hline 205 (S) & Acid & 26 & $10 / 3 / 12$ & Chronic interstitial nephritis. & Improved \\
\hline $130(\mathrm{~S})$ & Acid & $\begin{array}{l}\text { None } \\
\text { made. }\end{array}$ & $\cdots \cdots \cdots$ & $\begin{array}{c}\text { Chronic par. neph. (Some edema. } \\
\text { Chronic pul. } \\
\text { Always fever.) }\end{array}$ & Died \\
\hline$\cdots \cdots$ & Acid & F. Tr. & $11 / 2 / 12$ & $\begin{array}{l}\text { Chronic interstitial nephritis. } \\
\text { (Atony of bladder.) }\end{array}$ & Improved \\
\hline $\begin{array}{l}130(\mathrm{~S}) \\
\text { S0 (S) }\end{array}$ & Acid & 36 & $11 / 2 / 12$ & $\begin{array}{l}\text { Had marked amyloid change in } \\
\text { kidney, liver and spleen at } \\
\text { necropsy. }\end{array}$ & Died \\
\hline $\begin{array}{l}220(\mathrm{~S}) \\
250(\mathrm{~S})\end{array}$ & Acid & $\begin{array}{c}\text { Less than } \\
5 \\
\text { Trace } \\
1 \\
1\end{array}$ & $\begin{array}{r}11 / 22 / 12 \\
12 / 3 / 12 \\
1 / 6 / 13 \\
1 / 15 / 13\end{array}$ & $\begin{array}{l}\text { Chronic interstitial nephritis. } \\
\text { (Necropsy showed extreme art. } \\
\text { scl. of bl. ves., kidney, etc.) }\end{array}$ & Died \\
\hline $\begin{array}{l}180(\mathrm{~S}) \\
\text { to } \\
200(\mathrm{~S})\end{array}$ & Acid & 13 & $11 / 4 / 12$ & $\begin{array}{l}\text { Chronic interstitial nephritis. } \\
\text { (Empyema of frontal sinus, } \\
\text { secondary diagnosis.) }\end{array}$ & Died \\
\hline$\ldots \ldots$ & Acid & $\begin{array}{l}10 \\
5 \\
3\end{array}$ & $\begin{array}{r}12 / 6 / 12 \\
1 / 6 / 13 \\
2 / 3 / 13\end{array}$ & $\begin{array}{l}\text { Chronic interstitial nephritis. } \\
\text { (Secondary anemia.) }\end{array}$ & Improved \\
\hline $\begin{array}{l}\text { Within } \\
\text { normal } \\
\text { limits }\end{array}$ & Acid & $\begin{array}{l}32 \\
38\end{array}$ & $\begin{array}{l}1 / 9 / 13 \\
1 / 21 / 13\end{array}$ & $\begin{array}{l}\text { Chronic interstitial nephritis. } \\
\text { (Chronic card. valv. dis.) } \\
\end{array}$ & Improved \\
\hline $200(S)$ & Acid & $\begin{array}{l}16 \\
10\end{array}$ & $\begin{array}{l}1 / 9 / 13 \\
1 / 24 / 13\end{array}$ & $\begin{array}{l}\text { Chronic interstitial nephritis. } \\
\text { Congenital cystic kidney and } \\
\text { hydrothorax. }\end{array}$ & Improved \\
\hline $200(S)$ & Acid & 33 & $1 / 14 / 13$ & Chronic interstitial nephritis. & Died \\
\hline $220(\mathrm{~S})$ & Acid & $\begin{array}{c}\mathbf{5} \\
\text { Trace }\end{array}$ & $\begin{array}{r}1 / 16 / 13 \\
11 / 25 / 13\end{array}$ & Chronic interstitial nephritis. & Improved \\
\hline $170(\mathrm{~S})$ & Acid & 57 & $1 / 16 / 13$ & $\begin{array}{l}\text { Chronic interstitial nephritis. } \\
\text { (Diabetes not severe but may } \\
\text { be primary disease.) }\end{array}$ & Improved \\
\hline $180(\mathrm{~S})$ & Acid & $\begin{array}{l}11 \\
76\end{array}$ & $\begin{array}{l}1 / 25 / 12 \\
2 / 13 / 13\end{array}$ & $\begin{array}{l}\text { Chronic interstitial nephritis. } \\
\text { (Acute tonsillitis.) }\end{array}$ & Improved \\
\hline$\ldots \ldots$ & Acid & 48 & $2 / 19 / 13$ & $\begin{array}{l}\text { Chronic interstitial nephritis. } \\
\text { (Acute cardiac dilatation.) }\end{array}$ & Improved \\
\hline $190(\mathrm{~S})$ & Acid & $\begin{array}{l}40 \\
23 \\
13 \\
16 \\
10 \\
13 \\
31 \\
29 \\
66 \\
60 \\
46 \\
44\end{array}$ & $\begin{array}{r}10 / 16 / 12 \\
11 / 12 / 12 \\
12 / 10 / 12 \\
12 / 23 / 12 \\
1 / 10 / 13 \\
1 / 27 / 13 \\
2 / 10 / 13 \\
2 / 25 / 13 \\
4 / 2 / 13 \\
4 / 21 / 13 \\
5 / 6 / 13 \\
5 / 24 / 13\end{array}$ & $\begin{array}{l}\text { Chronic parenchy. nephritis. } \\
\text { Jan. 30, 1913, had double } \\
\text { decapsulation of kidneys. Since } \\
\text { then edema has disappeared. } \\
\text { Developed symptoms since Feb. } \\
19 \text {, 1913, of pul. tuberculosis } \\
\text { with fever. Discharged July } \\
\text { 8, 1913. Still fever. }\end{array}$ & Improved \\
\hline
\end{tabular}


TABLE 1.-Chronio Interstitial Nephritis.

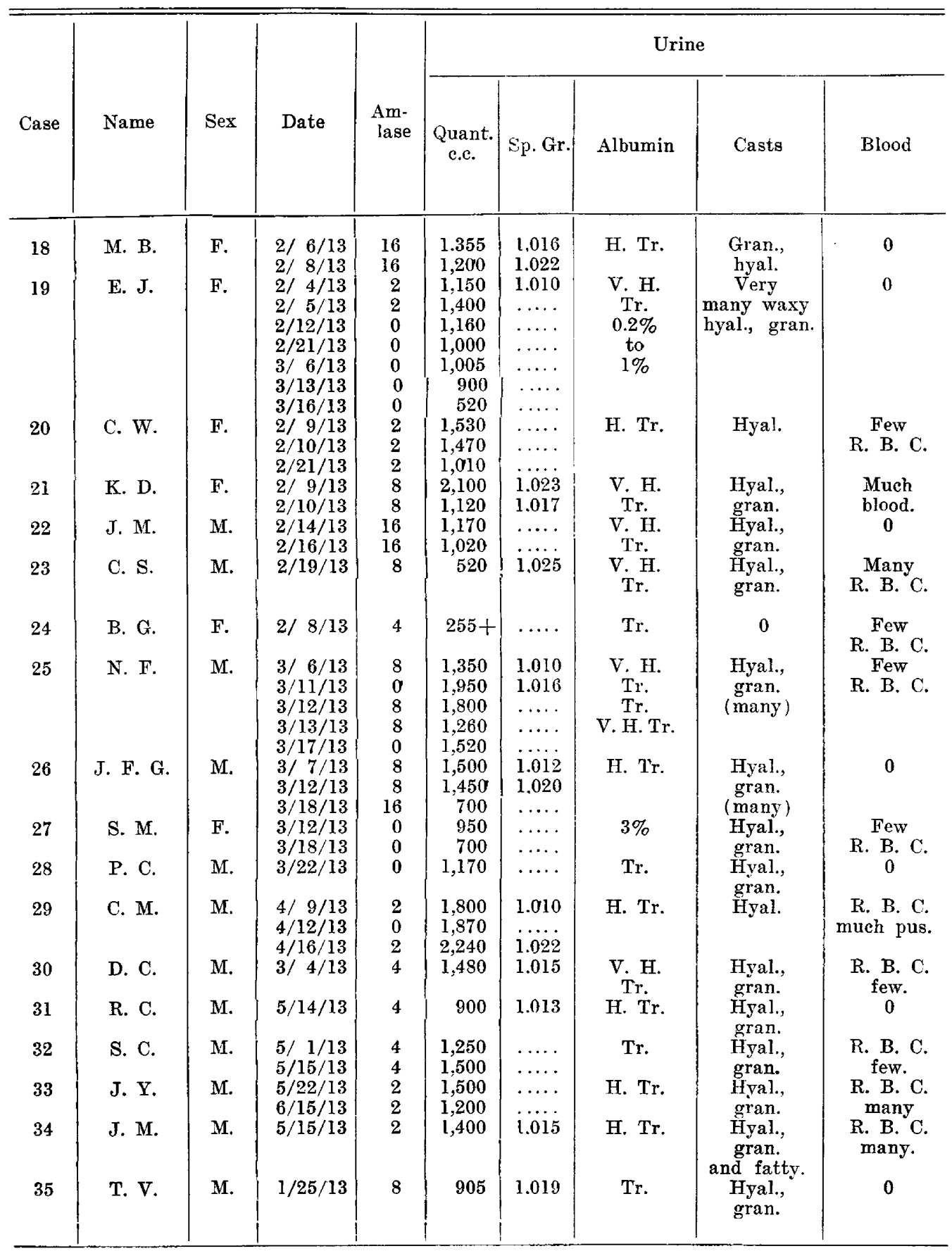




\begin{tabular}{|c|c|c|c|c|c|}
\hline \multicolumn{3}{|c|}{ Urine } & \multirow[b]{2}{*}{ Date } & \multirow[b]{2}{*}{ Disease } & \multirow[b]{2}{*}{ Result } \\
\hline $\begin{array}{l}\text { Blood } \\
\text { Pressure }\end{array}$ & Reaction & $\begin{array}{l}\text { Phenol- } \\
\text { sulphone- } \\
\text { phthalein } \\
\text { Per Cent. }\end{array}$ & & & \\
\hline $\begin{array}{l}130(\mathrm{~S}) \\
160(\mathrm{~S})\end{array}$ & Acid & $\begin{array}{c}33 \\
69 \\
3 \\
11 \\
10\end{array}$ & $\begin{array}{c}2 / 7 / 13 \\
3 / 10 / 13 \\
1 / 6 / 13 \\
1 / 27 / 13 \\
2 / 3 / 13\end{array}$ & $\begin{array}{l}\text { Chronic interstitial nephritis. } \\
\text { (Chr. card. valv. dis.) } \\
\text { Chronic interstitial nephritis. } \\
\text { Necropsy: Chronic dif. neph. } \\
\text { (amyloid.) Aortic and mitral } \\
\text { endocarditis. ( } \mathrm{R} \text { e g u rgitation } \\
\text { and stenosis.) }\end{array}$ & Improved \\
\hline$\ldots \ldots$ & Neutral & $\begin{array}{l}\text { F. Tr. } \\
\text { F. Tr. }\end{array}$ & $\begin{array}{l}1 / 3 / 13 \\
2 / 14 / 13\end{array}$ & Chronic interstitial nephritis. & $\begin{array}{l}\text { Unim: } \\
\text { proved }\end{array}$ \\
\hline $180(\mathrm{~S})$ & Neutral & 58 & $2 / 7 / 13$ & Chronic interstitial nephritis. & Improved \\
\hline $215(\mathrm{~S})$ & Acid & 35 & $2 / 13 / 13$ & Chronic interstitial nephritis. & Improved \\
\hline $200(\mathrm{~S})$ & Acid & 53 & $\cdots \cdots \cdots$ & $\begin{array}{l}\text { Chronic interstitial nephritis. } \\
\text { Cardiac hypertrophy. Tabes } \\
\text { dor. }\end{array}$ & Improved \\
\hline $240(\mathrm{~S})$ & Acid & 28 & $\begin{array}{l}2 / 17 / 13 \\
3 / 5 / 13\end{array}$ & $\begin{array}{l}\text { Necropsy: Chronic dif. neph. } \\
\text { Hemorrhage into cerebrum. }\end{array}$ & Died \\
\hline $\begin{array}{l}\text { Above } \\
160(\mathrm{~S})\end{array}$ & Acid & $\begin{array}{l}12 \\
19\end{array}$ & $\begin{array}{l}3 / 4 / 13 \\
3 / 8 / 13\end{array}$ & Chronic interstitial nephritis. & Improved \\
\hline$\ldots \ldots$ & Acid & $\begin{array}{l}44 \\
42\end{array}$ & $\begin{array}{l}3 / 10 / 13 \\
3 / 22 / 13\end{array}$ & Chronic interstitial nephritis. & Improved \\
\hline$\ldots \ldots$ & Neutral & $\begin{array}{l}\text { None } \\
\text { made. }\end{array}$ & & Chronic par. nephritis. & Improved \\
\hline $150(\mathrm{~S})$ & Acid & 13 & $4 / 19 / 13$ & Acute nephritis; bronchitis. & Cured \\
\hline$\cdots \cdots$ & $\begin{array}{l}\text { Acid } \\
\text { Acid }\end{array}$ & $\begin{array}{l}\text { Trace } \\
\text { Trace } \\
\text { Trace } \\
\quad 28\end{array}$ & $\begin{array}{l}4 / 8 / 13 \\
4 / 15 / 13 \\
5 / 12 / 13 \\
4 / 27 / 13\end{array}$ & $\begin{array}{l}\text { Pyelitis (bilateral). Uremia. } \\
\text { Dela y e d exer e tion urine, } \\
\text { bloody, from left ureter. } \\
\text { Chronic parenchymatous neph. }\end{array}$ & $\begin{array}{c}\text { Died } \\
\text { Improved }\end{array}$ \\
\hline$\cdots \cdots$ & Acid & 15 & $5 / 9 / 13$ & Chronic interstitial nephritis. & Died \\
\hline$\ldots \ldots$ & Acid & 52 & $3 / 7 / 13$ & Chronic interstitial nephritis. & Improved \\
\hline $180(\mathrm{~S})$ & Acid & $\begin{array}{c}\mathbf{5} \\
\text { Trace }\end{array}$ & $\begin{array}{l}5 / 20 / 13 \\
6 / 13 / 13\end{array}$ & Chronic interstitial nephritis. & Died \\
\hline$\cdots \cdots \cdots$ & Acid & $\begin{array}{l}24 \\
16\end{array}$ & $\begin{array}{l}5 / 13 / 13 \\
6 / 13 / 13\end{array}$ & $\begin{array}{l}\text { Chronic interstitial nephritis. } \\
\text { (Chr. card. valv. dis.) }\end{array}$ & Died \\
\hline $140(\mathrm{~S})$ & Acid & $\begin{array}{l}70 \\
54\end{array}$ & $\begin{array}{l}1 / 13 / 13 \\
1 / 23 / 13\end{array}$ & Chronic interstitial nephritis. & Died \\
\hline
\end{tabular}


"little albumin" give subnormal "d" readings; eleven cases which have "much albumin" give subnormal " $d$ " readings, Case 12 showing both; seven cases which have "much albumin" give normal or high normal "d" readings; while two cases in which there was little albumin give low normal " $d$ " readings, and both these cases give normal phthaleins.

Cases 1, 17 and 25 do not permit of classification as regards this subject, as all have shown much albumin with varying " $d$ " readings.

No hard-and-fast conclusions can be drawn from these figures, both because the method of estimating the quantity of albumin is purely an arbitrary one, and because the number of cases is not sufficient, but the results are at least suggestive of the fact as observed by other investigators that in cases of nephritis with high albumin content there is a greater tendency to normal or high normal " $d$ " values than in those with small albumin content, when the "d" readings are almost invariably subnormal, and further, in those urines, when in spite of a high albumin content, persistently subnormal "d" readings are found, it can be assumed that the functional damage has been all the more severe. In all cases we must not forget the possible effect of blood if that be present. Also the presence of pus of extra-renal origin as a factor in the production or intensification of the albumin test must not be overlooked, in view of what Neuman ${ }^{16}$ asserts, that is, that pus has no influence on the " $\mathrm{d}$ " readings. ${ }^{32}$

The question of dilution and its effect on the quantitative estimation of amylase is one that has been the subject of much discussion on the part of many observers. Wynhausen, ${ }^{13}$ Marino, ${ }^{15}$ Corbett, ${ }^{8}$ Rosenthal ${ }^{14}$ and Benczur ${ }^{12}$ argue that its influence is a very limited one, and in the range of normal twenty-four-hour urines no appreciable effect is noted on the "d" readings. Wynhausen ${ }^{13}$ quoted a case in which two readings were identical in the case of a patient who had 700 c.c. of urine, specific gravity 1.015 , and a month later had 2,500 c.c. of urine, specific gravity 1.015. All the other authors mentioned above quote many similar cases. They agree that only in cases of extreme variations in amount do the " $d$ " values change. One of my patients who had shown a reading of 32 on two occasions, only five days apart, with urine quantity amounting to 940 c.c. and 1,300 c.c., showed fifteen days later a reading of 8 , with a urine quantity of 4,000 c.c. This was a patient who had an exophthalmic goiter. (Case 10, Table 3), whose condition throughout her stay changed very little. In each instance the " $d$ " reading was within normal limits, although the effect of the diuresis on the last " $\mathrm{d}$ " reading can readily be seen. Extremely low amounts of urine (ünder 500) are found only, as

32. Neuman's work appeared after this investigation had been concluded and the tables made out. Allusions to his work have been included only as they could be added to the text and had reference to what has already been written. His work on the effect of dilution on the " $\mathrm{d}$ " reading has not been alluded to as no time to study its application has been available. 
a rule, in renal and cardiac condition, and the renal cases in spite of this show a low " $\mathrm{d}$ " reading. If in a case of this kind the reading should be 8 , for instance, in view of the concentration of the urine we would be justified in assuming that were the quantity of the urine within normal limits, the reading would be lower. The effect of concentration on the "d" value may be noted in Case 7, Table 2. Here we have an approximately normal excretion of phenolsulphonephthalein and a high normal "d" reading, 32 on three occasions. It is probable that urine within normal limits in this case would have brought the reading to a lower "d" worth. In general, it may be assumed that only when a urine is abnormally large or abnormally small in quantity allowance need be made for dilution or concentration in judging the value of the actual " $d$ " reading.

Rosenthal ${ }^{14}$ has made an attempt to estimate what he terms the "absolute diastatic strength" of the urine. This he does by multiplying the twenty-four-hour total by the " $\mathrm{d}$ " reading and then dividing by 2 ; for example, daily output 1,500 c.c., 0.2 c.c. of urine digests 2 c.c. 0.1 per cent. starch solution, therefore the absolute diastatic strength $=$

$\frac{1,500 \times 10}{2}=\pi, 500$, or 500 per cent. concentration.

I do not see that anything is gained by this method, and as Corbett aptly comments, "the results would vary out of all proportion to slight changes in the daily excretion," which in Rosenthal's series they do.

Another factor to be considered is the influence of fever on the " $\mathrm{d}$ " values, and here all observers agree that very high readings are found in acute infectious diseases. Rosenthal ${ }^{14}$ demonstrates the influence of high temperatures in a case of nephritis which developed lobar-pneumonia. During the febrile period amylase was present in normal amounts; after subsidence of the fever no amylase could be found in the urine, while the clinical picture was at all times that of nephritis.

Having discussed the various conditions which may affect the action of amylase in the urine and having seen that in normal individuals in a twenty-four-hour specimen the " $\mathrm{d}$ " readings vary within narrow limits, it is appropriate at this point to summarize briefly actual figures obtained for the " $\mathrm{d}$ " values of normal twenty-four-hour urine specimens. Wohlgemuth, ${ }^{7}$ in a large series of normal cases, says it varies between

$$
\mathrm{d} \frac{38^{\circ}}{30^{\prime}}=16 \text { to } 32
$$

never exceeding 64 . Corbett, ${ }^{8}$ working with slightly different dilutions, gives 6.6 to 33.3 with an average of from 10 to 24 . Rosenthal, ${ }^{14}$ whose method of calculating his readings is different, gives 10 to 25 when his results are translated into terms of the original Wohlgemuth method. 
From repeated examination of eight normal cases and many other cases whose clinical condition gave no reason to suspect altered " $\mathrm{d}$ " readings, $I$ have reached the conclusion that " $\mathrm{d}$ " $=8$ to 32 is the normal range for twenty-four-hour urine. The large majority of the readings were between 16 and 32 , as given by Wohlgemuth. I have never had a normal urine in which a reading of 64 has been reached.

Coming to the study of altered amylolytic power of the urine observations in the literature, so far it has been confined mainly to four conditions, that is, nephritis, diabetes, pancreatic disease and the so-called diabetes insipidus. Many other conditions have also been investigated, but the most positive and important results have been obtained in these four conditions.

\section{NEPHRITIS}

This includes all forms of the disease ranging from the acute type to the chronic (tubular, vascular or mixed) types, and includes also such conditions as pyelitis and renal calculus. Hirata, ${ }^{33}$ working under Wohlgemuth's direction, produced sublimate, chromate and uranium nephritis in rabbits, estimating the amylolytic power of their urine before and after the production of nephritis. He found that the " $\mathrm{d}$ " values in all forms of nephritis were markedly decreased with a coincident rise on the "d" value of the blood, which was not always as marked as that shown in the urine. In view of the fact that these forms of experimental nephritis interfere mainly with tubular function, it would seem probable that amylase was excreted in largest quantities via this route.

This work on animals has been further substantiated by the investigations on patients suffering from various forms of nephritis. Wohlgemuth, ${ }^{17}$ Wynhausen, ${ }^{13}$ Marino, ${ }^{15}$ Rosenthal, ${ }^{14}$ and more recently Corbet ${ }^{8}$ and Neuman ${ }^{16}$ give distinctly low "d" readings for nephritis in general. Benczur ${ }^{12}$ does not agree with the above-mentioned investigators, although he admits low readings in some of his cases of nephritis. He reports only eleven cases and five of these showed low "d" values. Two of the other cases showed very high readings. Benczur comes to the conclusion that no reliable information can be drawn from the test. It is interesting to note in this connection that although Benczur could not find any "essential" difference between $a \frac{37^{\circ}}{24} \mathrm{hr}$. and those of twenty-four-hour specimens, his five cases of nephritis with low readings were all twenty-four-hour specimens, while the other specimens examined, taken in hunger periods, when as Wohlgemuth shows, the " $\mathrm{d}$ " readings are highest, all give much higher amylase values.

Certainly the preponderance of evidence so far adduced demonstrates that in the large majority of so-called nephritides the amylase value of

33. Hirata, G.: Biochem. Ztschr., 1910, xxviii, 23. 
twenty-four-hour specimens of urine is markedly below normal and in very few of the remaining cases does it exceed low normal limits. It must be admitted, on the other hand, that undoubted cases of severe chronic diffuse nephritis, proved by necropsy, and by the presence of every characteristic clinical symptom, have shown normal " $\mathrm{d}$ " readings, but these cases may also show one of the other functional tests to be normal.

In all of the thirty-five cases of renal disease shown in Table 1 , the "d" value of the urine has been estimated one or more times. In all but two of the cases the phenolsulphonephthalein test of Rowntree and Geraghty has been made, and in the majority of instances on the day preceding the "d" estimation.

A word as to the technic of performing the phenolsulphonephthalein test in the First and Second Medical Divisions of the Presbyterian Hospital may be of service. The patient is given 200 to 300 c.c. of water twenty minutes previous to the administration of $6 \mathrm{mg}$. of the drug, which is given intramuscularly in all but a few instances, when it is given intravenously. The time of first appearance is noted. The specimen for this can usually be obtained by getting patient to void; if this is not possible, a catheter is used. Then the urines collected the first and second hours are estimated separately. The figures given are the totals of the first-and second-hour amounts. The time of appearance and the separate amounts for each hour are not deemed of sufficient importance in their relation to the "d" values to be tabulated. With the estimation of amylase, the quantity, specific gravity, reaction, albumin, casts and blood were noted in all twenty-four-hour specimens, not only on day of "d" estimation, but at intervals during their stay in the hospital. Albumin and casts are tabulated as an average finding in several examinations during the test periods or albumin as a separate finding when its relation to the " $\mathrm{d}$ " reading is important.

The diagnoses appended are clinical and made at the time of discharge of patient. Secondary conditions and necropsy findings are given when they occur.

From Table 1, if we consider eight as low normal limit, it will be seen that twenty-three of the thirty-five cases of nephritis, or 65.7 per cent., show persistent subnormal or absent " $d$ " values. If we compare these values with the phenolsulphonephthalein readings we find that twenty of the corresponding cases also show a lowered phthalein excretion, assuming anything below fifty to be subnormal. ${ }^{34}$ of the remaining three cases, one (27) was a severe case of nephritis and the phenolsulphonephthalein test was not made, as it was not deemed advisable to

- 34. Cases 15 and 24 are here included as the later high readings for phenolsulphonephthalein were not explained clinically. 
disturb the patient; while in the other two cases (14 and 32), which showed phenolsulphonephthaleins of 57 per cent. and 52 per cent., respectively, with " $d$ " readings of four in each case, no definite theory can be advanced to explain the discrepancy, unless, as in Case 14, the mild degree of diabetes and secondary anemia can explain it. Low "d" read. ings in these conditions having been found by other observers, Marino, ${ }^{15}$ Neuman, ${ }^{16}$ Wynhausen, ${ }^{13}$ etc. Case 32 , however, cannot be explained on any such basis.

Of the twelve cases which do not show subnormal " $d$ " values in every estimation, three show it in two or more readings and their average would be subnormal. Two of these three cases, namely, Cases 8 and 25, show low phenolsulphonephthaleins, whereas the other case (1) shows one lowered phthalein and two readings above normal. This latter case was one of severe nephritis and the patient died in a uremic condition.

This leaves nine cases of nephritis, as evidenced by clinical signs, in which there was a low normal or normal " $d$ " reading. Of these, one (4) did not have the phenolsulphonephthalein test made. Of the remaining eight, five, that is, Cases $12,16,18,22$ and 26 , gave normal " $d$ " readings and slightly subnormal phthalein readings, while three cases, namely, 21, 23 and 35 , gave normal " $\mathrm{d}$ " and phenolsulphonephthalein readings.

To summarize, then :

In thirty-three cases both tests were made.

In twenty-two cases subnormal readings were shown for both tests.

Three of the remaining eleven show diminished " $\mathrm{d}$ " with normal phenolsulphonephthalein (Cases 1, 14 and 32).

Five show diminished phenolsulphonephthalein with normal " $\mathrm{d}$ " readings.

Three of these cases $(16,18$ and 26$)$ show a diminution of phthalein, which was very little below normal, Case 18 having at one time 69 per cent. The remaining three agree in that they show normal " $d$ " and phenolsulphonephthalein readings.

Case 17, J. T., calls for more detailed comment. I have included this case among those that give a low reading for both tests, because at the height of his kidney condition they both showed very low readings. This was in the latter part of January. At that time the edema was extreme, the urine quantities very small, blood-pressure was high and the patient was rapidly going into uremia. January 30 a double decapsulation of the kidneys was made, and from that time on until July, when he was discharged, his kidney condition improved remarkably. The edema disappeared, the urine increased and the blood-pressure fell. Both functional tests came from extremely low readings to high normal readings; one amylase reading, March 6, 1913, showed low normal limit, but immediately rose again. The patient developed pulmonary tuberculosis 
a month after the operation, and although this improved slightly, it still persisted at the time of his leaving the hospital. Three high normal "d" readings were obtained before fever developed, which was persistent but slight.

In Cases 1, 8 and 25, we find that there is not absolute agreement in all of the "d" readings; taken as an average, they are below normal, and should be interpreted as such. In Case 1 it must be noted that the phthalein average was normal.

It is of interest further to note that in every case when the " $d$ " value was normal with small amounts of albumin the phenolsulphonephthalein was also normal.

In Case 8, it is of interest to note that the reading of 16 was obtained during a period of marked clinical improvement, whereas the other readings were obtained during the reverse condition.

As regards the relationship existing between the " $\mathrm{d}$ " reading and the severity of the nephritis, I am unable to draw any definite conclusions. In this connection, Wynhausen ${ }^{13}$ states that the lower the " $\mathrm{d}$ " reading the more severe the nephritis. Some patients with low and in some cases absent " $\mathrm{d}$ " readings, were discharged apparently improved. Of course, there has not been sufficient time in some cases to determine what the outcome will be, while in others there is no data as to what may have occurred after the patient left the hospital.

On the other hand, three patients with normal or high normal "d" readings have died. In one of these cases (No. 4) death was probably due to complicating disease. Excluding this case, it will be seen that nine of the eleven patients who died had low " $d$ " readings.

\section{CARDIAC DISEASE}

In Table 2 nineteen cases of cardiac disease are tabulated. In some of these at certain times during which the patients stayed in the hospital, there were marked evidences of acute myocardial insufficiency. In all of the nineteen cases phenolsulphonephthalein and " $d$ " readings were made, and in seven of the cases two phthalein readings were made, one at the time of acute decompensation and a second one later. Six of these cases showed low readings at the time of decompensation and normal readings - later. This was rather a striking feature of these cases, a fact that has already been pointed out by Rowntree, Geraghty and Fitz, ${ }^{35}$ who produced varying grades of chronic passive congestion of the kidneys in dogs, and found in the severe types of congestion a marked diminution in the phthalein output. This, Rowntree and Fitz $^{36}$ later confirmed in their clinical findings in a series of cardiac cases, which at the time of acute

35. Rowntree, Geraghty and Fitz: The ARChIves. Int. Med., 1913, xi, 121.

36. Rowntree and Fitz: The Archives Int. Med., 1913, xi, 258. 
TABLE 2.-Chrontc Cardio-Valvula

\begin{tabular}{|c|c|c|c|c|c|c|c|c|c|}
\hline \multirow[b]{2}{*}{ Case } & \multirow[b]{2}{*}{ Name } & \multirow[b]{2}{*}{ Sex } & \multirow[b]{2}{*}{ Date } & \multirow[b]{2}{*}{$\begin{array}{l}\text { Amy- } \\
\text { lase }\end{array}$} & \multicolumn{5}{|c|}{ Urine } \\
\hline & & & & & $\begin{array}{l}\text { Amt. } \\
\text { c.c }\end{array}$ & Sp. Gr. & Albumin & C asts & Blood \\
\hline 1 & M. F. & F. & $10 / 31 / 13$ & 16 & 1,620 & 1.015 & 0 & 0 & \\
\hline 2 & F. P. & M. & $1 / 8 / 13$ & 128 & $350+$ & 1.025 & H. Tr. & Hyal., & Much \\
\hline 3 & J. F. & M. & $1 / 10 / 13$ & 16 & 1,470 & 1.030 & Trace & $\begin{array}{l}\text { Hyal., } \\
\text { gran. }\end{array}$ & $\begin{array}{l}\text { Few } \\
\text { R. B. C. }\end{array}$ \\
\hline 4 & J. C. & M. & $1 / 13 / 13$ & 8 & 2,400 & 1.020 & 0 & 0 & 0 \\
\hline 5 & F. C. & M. & $\begin{array}{l}1 / 12 / 13 \\
1 / 15 / 13\end{array}$ & $\begin{array}{l}16 \\
32\end{array}$ & $\begin{array}{l}1,730 \\
1,290\end{array}$ & 1.025 & H. Tr. & $\begin{array}{l}\text { Hyal., } \\
\text { gran. }\end{array}$ & 0 \\
\hline 6 & J. H. & M. & $1 / 16 / 13$ & 16 & 1,530 & 1.015 & F. Tr. & Hyal. & 0 \\
\hline 7 & F. R. & M. & $\begin{array}{l}1 / 18 / 13 \\
1 / 31 / 13\end{array}$ & $\begin{array}{l}32 \\
32\end{array}$ & $\begin{array}{l}520 \\
300\end{array}$ & $\begin{array}{l}1.030 \\
\ldots .\end{array}$ & $\begin{array}{l}\text { V. F. } \\
\text { Trace }\end{array}$ & 0 & 0 \\
\hline 8 & S. C. & F. & $\begin{array}{l}2 / 6 / 13 \\
1 / 22 / 13 \\
2 / 17 / 13\end{array}$ & $\begin{array}{l}32 \\
32 \\
64\end{array}$ & $\begin{array}{r}450 \\
605 \\
1.105\end{array}$ & $\begin{array}{l}1.029 \\
\ldots \ldots\end{array}$ & $\begin{array}{l}\text { V. H. } \\
\text { Trace } \\
\text { F. Tr. }\end{array}$ & $\begin{array}{l}\text { Hyal., } \\
\text { gran. }\end{array}$ & R. B. C. \\
\hline 9 & F. S. & F. & $1 / 25 / 13$ & 16 & 680 & 1.017 & F. Tr. & 0 & 0 \\
\hline 10 & R. & M. & $2 / 5 / 13$ & 2 & 1,150 & $\ldots .$. & Trace & 0 & $0^{*}$ \\
\hline 11 & J. V. & M. & $2 / 4 / 13$ & 8 & 3,210 & 1.030 & H. Tr. & 0 & 0 \\
\hline 12 & S. P. & F. & $\begin{array}{l}2 / 12 / 13 \\
2 / 14 / 13\end{array}$ & $\begin{array}{l}32 \\
16\end{array}$ & $\begin{array}{r}450 \\
1,025\end{array}$ & $\ldots$. & $\begin{array}{l}\text { V. F. } \\
\text { Trace }\end{array}$ & Hyal & 0 \\
\hline 13 & L. D. & F. & $2 / 16 / 13$ & 16 & 910 & $\ldots$. & $\begin{array}{l}\text { V. F. } \\
\text { Trace }\end{array}$ & 0 & 0 \\
\hline 14 & D. C. & M. & $2 / 17 / 13$ & 32 & 1,745 & $\ldots$. & F. Tr. & Hyal. & 0 \\
\hline 15 & P. D. L. & M. & $\begin{array}{l}2 / 18 / 13 \\
3 / 11 / 13\end{array}$ & $\begin{array}{l}16 \\
16\end{array}$ & $\begin{array}{r}880 \\
1,700\end{array}$ & $\begin{array}{l}\ldots . . \\
\ldots \ldots\end{array}$ & H. Tr. & $\begin{array}{l}\text { Hyal., } \\
\text { gran. }\end{array}$ & $\begin{array}{l}\text { Many } \\
\text { R. B. C. }\end{array}$ \\
\hline 16 & D. & F. & $\begin{array}{l}3 / 2 / 13 \\
3 / 13 / 13\end{array}$ & $\begin{array}{l}8 \\
8\end{array}$ & $\begin{array}{r}1,000 \\
930\end{array}$ & $\ldots$. & $\begin{array}{l}\text { V. F. } \\
\text { Trace }\end{array}$ & $\begin{array}{l}\text { Few } \\
\text { hyal. }\end{array}$ & 0 \\
\hline 17 & M. F. & F. & $\begin{array}{l}4 / 8 / 13 \\
4 / 9 / 13\end{array}$ & $\begin{array}{l}16 \\
16\end{array}$ & $\begin{array}{l}1,350 \\
1,400\end{array}$ & 1.020 & F. Tr. & $\begin{array}{l}\text { Hyal., } \\
\text { gran. }\end{array}$ & $\begin{array}{l}\text { Occ. } \\
\text { R. B. C. }\end{array}$ \\
\hline $\begin{array}{l}18 \\
19\end{array}$ & $\begin{array}{l}\text { A. W. } \\
\text { K. W. }\end{array}$ & $\begin{array}{l}\text { F. } \\
\text { F. }\end{array}$ & $\begin{array}{l}4 / 9 / 13 \\
1 / 15 / 13\end{array}$ & $\begin{array}{l}16 \\
16\end{array}$ & $\begin{array}{l}970 \\
440\end{array}$ & $\begin{array}{l}1.025 \\
1.015\end{array}$ & $\begin{array}{l}\text { F. Tr. } \\
\text { H. Tr. }\end{array}$ & $\begin{array}{c}0 \\
\text { Coarsely }\end{array}$ & $\begin{array}{c}0 \\
\text { Mod. }\end{array}$ \\
\hline 18 & K. W. & & $1 / 15 / 13$ & 16 & & 1.010 & & $\begin{array}{l}\text { gran., } \\
\text { hyal. }\end{array}$ & R. B. C. \\
\hline
\end{tabular}

* Blood-pressure, systolic, 110. 


\begin{tabular}{|c|c|c|c|}
\hline \multicolumn{2}{|c|}{ Urine } & \multirow[b]{2}{*}{ Diagnosis } & \multirow[b]{2}{*}{ Result } \\
\hline $\begin{array}{l}\text { Phenol- } \\
\text { sulphone- } \\
\text { phthalein } \\
\text { Per Cent. }\end{array}$ & Date & & \\
\hline $\begin{array}{c}65 \\
8 \\
52 \\
65\end{array}$ & $\begin{array}{l}10 / 18 / 12 \\
11 / 5 / 12 \\
11 / 11 / 12 \\
12 / 6 / 12\end{array}$ & $\begin{array}{l}\text { Chronic cardio-valvular disease. (This was during an } \\
\text { acute attack of decompensation.) }\end{array}$ & Improved \\
\hline 33 & $1 / 7 / 13$ & $\begin{array}{l}\text { Chronic cardiac hypertrophy. Cardiac dilatation. Emph- } \\
\text { ysema of lungs. }\end{array}$ & Died \\
\hline 43 & $1 / 8 / 13$ & Chronic cardio-valvular disease. & Died \\
\hline 53 & $1 / 11 / 13$ & Chronic cardio-valvular disease. & Improved \\
\hline $\begin{array}{l}35 \\
62\end{array}$ & $\begin{array}{l}12 / 19 / 12 \\
12 / 23 / 12\end{array}$ & Chronic cardiac insufficiency and myocarditis. & Improved \\
\hline 32 & $12 / 30 / 12$ & ('hronic cardio-valvular disease; aortitis. & Improved \\
\hline 57 & $1 / 14 / 13$ & 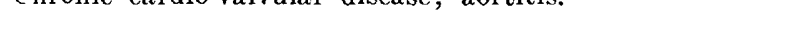 & 1mipi oved \\
\hline 47 & $1 / 16 / 13$ & $\begin{array}{l}\text { Chronic cardio-valvular disease; mitral regurgitation; } \\
\text { aortic regurgitation. (Necropsy diagnosis same as } \\
\text { clinical.) }\end{array}$ & Died \\
\hline $\begin{array}{c}4 \\
43\end{array}$ & $\begin{array}{l}1 / 20 / 13 \\
2 / 15 / 13\end{array}$ & Chronic cardiac insufficiency; hydrothorax. & Improved \\
\hline 64 & $1 / 23 / 13$ & $\begin{array}{l}\text { Chronic cardio-valvular disease; acute endocarditis } \\
\text { (fever.) }\end{array}$ & Died \\
\hline 51 & $2 / 2 / 13$ & $\begin{array}{l}\text { Chronic cardio-valvular disease; subacute articular rheu- } \\
\text { matism. }\end{array}$ & Improved \\
\hline 41 & $2 / 3 / 13$ & $\begin{array}{l}\text { Chronic cardio-valvular disease; auricular fibrillation; } \\
\text { aortic roughening and stenosis. }\end{array}$ & Improved \\
\hline $\begin{array}{l}20 \\
58\end{array}$ & $\begin{array}{l}2 / 2 / 13 \\
2 / 10 / 13\end{array}$ & Obesity and fatty heart. & Improved \\
\hline 84 & $2 / 14 / 13$ & $\begin{array}{l}\text { Chronic cardio-valvular disease; cardiac hypertrophy and } \\
\text { dilatation. }\end{array}$ & Improved \\
\hline 28 & $2 / 16 / 13$ & $\begin{array}{l}\text { Chronic cardio-valvular disease; septicemia (fever); } \\
\text { acute pericarditis. }\end{array}$ & Died \\
\hline $\begin{array}{l}21 \\
65\end{array}$ & $\begin{array}{l}2 / 17 / 13 \\
3 / 7 / 13\end{array}$ & $\begin{array}{l}\text { Chronic cardio-valvular disease; cardiac hypertrophy and } \\
\text { dilatation. }\end{array}$ & Improved \\
\hline $\begin{array}{l}56 \\
53\end{array}$ & $\begin{array}{l}3 / 1 / 13 \\
3 / 12 / 13\end{array}$ & Chronic cardio-valvular disease. & Improved \\
\hline 64 & $4 / 7 / 13$ & Chronic cardio-valvular disease. & Improved \\
\hline $\begin{array}{c}48 \\
34 \\
\text { Appear- } \\
\text { - ance after } \\
\text { one hour. }\end{array}$ & $\begin{array}{l}4 / 7 / 13 \\
1 / 17 / 13\end{array}$ & $\begin{array}{l}\text { Chronic cardio-valvular disease; hydrothorax. } \\
\text { Chronic cardio-valvular disease. }\end{array}$ & $\begin{array}{l}\text { Improved } \\
\text { Died }\end{array}$ \\
\hline
\end{tabular}


insufficiency showed low phthalein readings, with subsequent normal readings when the symptoms of decompensation cleared up and there was no concomitant nephritis.

In only one case in Table 2 have synchronous " $\mathrm{d}$ " and phenolsulphonephthalein readings been made during the time of decompensation, and later when compensation was restored. In this case (No. 8), when the phthalein was 4 per cent. the " $d$ " value was 32 , while nearly a month later the phthalein had increased to 43 per cent. and the " $\mathrm{d}$ " reading to 64. In another case (No. 19), during decompensation, when the phthalein was low, 34 per cent., the "d" reading was 16 , or normal.

In view of the fact that at the time of acute decompensation with diminished phenolsulphonephthalein excretion there is nearly always a large amount of albumin and many red blood-cells, we would not expect to find low "d" readings, and in the few cases observed this has proved to be the case; in fact, it has been rather high normal. So that we must conclude that the " $\mathrm{d}$ " reading shows very little if anything as regards functional activity during the periods of decompensation. If it can be shown that during the period of passive congestion, the urine, in spite of the presence of albumin and blood, gives a reading of 8 or 16, and then later when these two constituents are diminished or absent and the heart condition has improved, the reading is still the same or perhaps increased to 32 , we might readily assume that what in other circumstances would be taken for a normal reading had really been an expression of impaired function.

Generally speaking, twelve out of nineteen cases show normal phenolsulphonephthalein (after the period of decompensation, readings of 48 per cent. and $4^{7}$ per cent. included) and also normal " $d$ " readings. Of the remaining seven cases, three (3,8 and 11) showed only slightly impaired phthaleins with normal "d" readings and in none of these cases were further phenolsulphonephthalein tests made.

Three cases showed phthaleins ranging from 28 to 34 and normal " $\mathrm{d}$ " readings. Of these last three cases, Case 2 showed very high "d," 128 , but there was much blood in the specimen. Case 19 showed marked passive congestion of lungs and liver as well as kidneys during the stay in the hospital, and while the " $\mathrm{d}$ " reading is 16 , the possible influence of concentration of the urine, blood and albumin must be noted. The third case in this group is one where the phenolsulphonephthalein was 28 per cent. and the " $\mathrm{d}$ " reading 16 . Here there is a possible influence exerted by fever.

There is one atypical case in this group, and that is Case 10. Phthalein reads 51 per cent. and " $\mathrm{d}$ " 2 . That there was any renal involvement in this case was certainly not demonstrable clinically, either at the time of admission to the hospital or at any subsequent time. It must remain unexplained. 
In this series of cardiac cases there are only three in which the influence of urinary concentration should be considered, namely, Cases 7 and 19 . In both these cases we may consider a lower reading than that given to be possible, but the question as to what the " $\mathrm{d}$ " readings might have been, had the urine quantities been larger, was not determinable in either case. In Case 11, with 3,210 c.c. of urine and a reading of 8 , a higher reading, let us assume, to 16 would still have been in accord with what other cases of this series show.

In Table 3 thirteen cases of varied clinical conditions are tabulated. In this table each case or each group of cases must be considered separately.

\section{DIABETES}

First of all let us consider diabetes. Only two cases are to be found in this table, while the other two are found in Table 1 . It must be acknowledged that both cases in Table 1 cannot be considered as pure cases of diabetes. There was doubt in the minds of those who studied Case 14, R. P. (Table 1), as to whether the nephritis or glycosuric condition was the primary one. Also in Case 2, L. K. (Table 1), the question not only of nephritis but of dyspituitarism entered into the consideration. The glycosuria in this case was small but persistent, and failed to yield at all to dietary measures. We find that both these cases showed subnormal " $\mathrm{d}$ " readings with normal amounts of urine. The phthalein in one case, that of L. K. (Case 2, Table 1), was a shade under the normal, while with R. P. (Case 14) it was normal. The clinical findings all pointed to an underlying chronic nephritis, and for this reason I have classed them as nephritics.

Case 6, J. C., and Case 12, Wm. McG. (Table 3), were quite different, as the patients undoubtedly suffered from a primary diabetes mellitus, with large sugar outputs, and in Case 6 multiple furunculosis with diacetic acid and acetone in the urine. The urine quantity was low in Case 6 , but a portion was lost; in fact, twenty-four-hour specimens were very hard to obtain. The patient had a normal " $\mathrm{d}$ " reading with little albumin and little blood, as did also Wm. McG.

No conclusions from these four cases are justified.

Foster, ${ }^{4}$ as early as 1867, investigated amylase in the urine of diabetics, and concludes that its value does not exceed normal limits. $\mathrm{Le}^{37}$ and Benderesky ${ }^{38}$ found amylase increased in urine of diabetics. Lépine $^{5}$ found it decreased in the same disease. Enriquez and Binet ${ }^{39}$ found the amylase values high in diabetes, decreasing as the sugar content of the urine decreased. Loeper and Ficai ${ }^{40}$ found it decreased, while

37. Leo: Verhandl. d. VII. Kongr. f. inn. Med., 1888.

38. Benderesky: Virchows Arch. f. path. Anat., 1890, 121, 554.

39. Enriquez and Binet: Compt. rend. hebd. Soc. de biol. de Paris, 1908, lxv, 577.

40. Loeper and Ficai: Arch. de méd. experr. et d'anat. path., 1907, xix, 722. 
TABLE 3.-

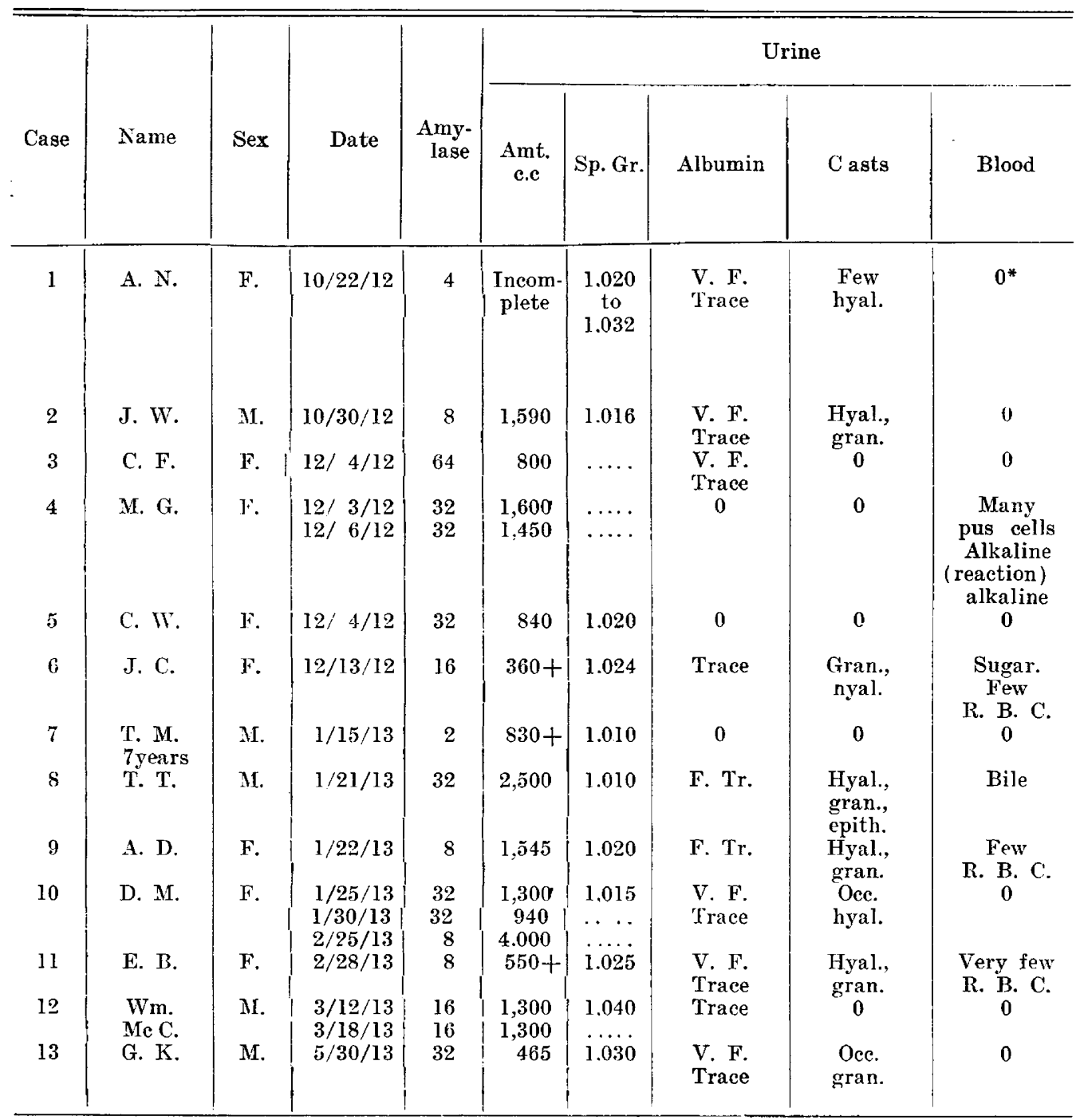

* B!ood-pressure, 130 systolic. 


\section{Miscellaneous Cases}

\begin{tabular}{|c|c|c|c|}
\hline \multicolumn{2}{|c|}{ Urine } & \multirow[b]{2}{*}{ Diagnosis } & \multirow[b]{2}{*}{ Result } \\
\hline $\begin{array}{l}\text { Phenol- } \\
\text { sulphone- } \\
\text { phthalein } \\
\text { Per Cent. }\end{array}$ & Date & & \\
\hline $\begin{array}{l}41 \\
63\end{array}$ & $\begin{array}{l}10 / 25 / 12 \\
10 / 30 / 12\end{array}$ & Brain tumor. (No necropsy.) & $\begin{array}{l}\text { Died } \\
\text { two days } \\
\text { after } \\
\text { bilateral } \\
\text { decom- } \\
\text { pression }\end{array}$ \\
\hline 24 & $10 / 26 / 12$ & $\begin{array}{l}\text { Multiple myelomata (Bence-Jones bodies in urine). Frac- } \\
\text { tured ribs. }\end{array}$ & Improved \\
\hline $\begin{array}{l}\text { None } \\
\text { made }\end{array}$ & $\ldots \ldots$ & Syph. arthritis knee. & Improved \\
\hline $\begin{array}{l}\text { None } \\
\text { made }\end{array}$ & $\cdots \cdots$ & Pyelitis. Cystitis of pregnancy. & Improved \\
\hline $\begin{array}{l}\text { None } \\
\text { made }\end{array}$ & $\ldots \ldots$ & Exophthalmic goiter; glycosuria. & Improved \\
\hline $\begin{array}{l}\text { None } \\
\text { made }\end{array}$ & $\ldots \ldots$ & $\begin{array}{l}\text { Diabetes mellitus; multiple staphylococeic abscesses } \\
\text { (fever). }\end{array}$ & Improved \\
\hline $\begin{array}{l}\text { None } \\
\text { made }\end{array}$ & $\ldots \ldots$ & Diabetes insipidus. & Improved \\
\hline $\begin{array}{l}\text { None } \\
\text { made }\end{array}$ & $\ldots \ldots$ & Hypertrophic cirrhosis of liver; cholangitis; ascites. & Improved \\
\hline 58 & $1 / 21 / 13$ & Complete abortion; albuminuria of pregnancy. & Improved \\
\hline 69 & $2 / 12 / 13$ & Exophthalmic goiter. & Improved \\
\hline $\begin{array}{l}\text { None } \\
\text { made }\end{array}$ & $\cdots \cdots$ & Asthma. & Improved \\
\hline $\begin{array}{l}\text { None } \\
\text { made }\end{array}$ & $\ldots \ldots$ & Diabetes mellitus; syphilis. & Improved \\
\hline 47 & $5 / 26 / 13$ & Chronic bronchitis. & Improved \\
\hline
\end{tabular}


Clark $^{41}$ found it absent. These were the most important contributions to the literature on this subject prior to 1908, when Wohlgemuth proposed the "starch iodin" method. All investigations prior to this had lacked reliable and uniform methods of estimating amylase, consequently these results are questionable.

Wohlgemuth ${ }^{17}$ with four cases, Wynhausen ${ }^{13}$ with forty, Rosenthal ${ }^{14}$ with ten and Marino ${ }^{15}$ with ten, find generally low readings in diabetes, some cases showing entire absence of amylase. Corbett ${ }^{8}$ confirms this. Benczur ${ }^{12}$ denies any variation from normal. None of the preceding writers seem to appreciate the possible effect of the tremendous diuresis which usually accompanies this disease, as a factor in lowering the "d" reading, or if they do, they merely add that there seems to be no relationship. Corbett ${ }^{8}$ does, but in spite of this, insists on subnormal readings for the majority of cases under treatment. Wynhausen ${ }^{13}$ says that the lower the " $d$ " reading the more severe the disease and the higher the reading the milder the disease. Another very important complicating factor, which is so often found in diabetes, is nephritis, and this in itself would account for low " $\mathrm{d}$ " readings. Wynhausen ${ }^{13}$ and Rosenthal" acknowledge its presence in the large majority of their very low "d" readings, but fail to appreciate its importance. Marino ${ }^{15}$ also merely alludes to it. Even in those cases in which no urinary evidences of nephritis are present, we cannot exclude varying degrees of kidney damage as evidenced, for instance, by decreased permeability for sugar itself, increased blood-pressure, etc.

In view of the great importance of these two factors, namely, extreme diuresis and nephritis, on the values of the " $\mathrm{d}$ " readings apart from any other condition, it does not seem justifiable in the light of our present knowledge to attribute the low "d" readings or even the absence of amylase to diabetes per se, but rather to regard them as evidences of a complicating condition.

Case 2, L. K., and Case 14, R. P. (Table 1), with low "d" readings, are certainly suggestive of the above, particularly when contrasted with Case 6, J. C. and Case 12, Wm. McG. (Table 3), who, without evidence of renal disease, give normal " $d$ " readings.

Diabetes Insipidus.-Case 7, T. M. (Table 3), a child aged 7, is the only case of the kind that I encountered. Strauss ${ }^{42}$ reported two cases in which not only was there no amylase found, but also no pepsin. The absence of the latter had only been met twice before, once in a case of uremia and the other in a case of carcinoma of the stomach. Rosenthal ${ }^{43}$ reports a case in which he also failed to find amylase in the urine, except

41. Clark: Glasgow Med. Jour., 1905, June, 632.

42. Straus, H.: Deutsch. med. Wehnschr., 1912, iv, 163.

43. Rosenthal, A.: Berl. klin. Wehnschr., 1912, xlix, 1265. 
in an oceasional examination, when it was greatly diminished. Benczur ${ }^{12}$ reports one case in which it was present in normal amount. Braunschweig, ${ }^{44}$ working in Straus' clinic, has also failed to find pepsin in the urine of such patients. The case (No. 7) reported in Table 3 shows the amylolytic ferment to be greatly diminished.

M. G. (Case 4, Table 3) was not included under the nephritics, as the condition was confined to the right kidney alone, and at the time of these examinations there was no definite evidence of kidney involvement under cystoscopic examination. This evidence was present one month later.

A. N. (Case 1, Table 3) shows a possibility of some renal involvement, but aside from a very faint trace of albumin and a few hyaline casts, there was no definite evidence from a clinical standpoint. It must be regarded as an unexplained case of low " $\mathrm{d}$ " reading. The patient died two days after bilateral decompression; no tumor was found; there was no necropsy.

T. T. (Case 8, Table 3) had bile in the urine, and is interesting from the standpoint of what Wohlgemuth ${ }^{45}$ has shown, namely, that bile in small amounts accelerates amylolytic action, while in large amounts it inhibitis the action.

It is to be regretted that no cases of pancreatic disease have been studied in view of the tremendously high " $\mathrm{d}$ " readings so uniformly found in these cases.

\section{CONCLUSIONS}

1. The amount of amylase in the twenty-four-hour specimen of a normal individual estimated by the Wohlgemuth method varies within very narrow limits, and for a given case is almost a constant factor.

2. The " $d$ " value of the urine, in the vast majority of cases of chronic or acute nephritis, is subnormal or totally absent. In the preceding series of thirty-five cases, 7\%.1 per cent. show this.

3. Only in extreme variations in concentration under 500 and over 2,500 c.c. can this factor be considered to have appreciable influence on the "d" reading, and under these circumstances due allowance should be made in the interpretation of values of " $\mathrm{d}$ " obtained.

4. The majority of normal readings obtained in cases of chronic nephritis were from urines containing considerable albumin, seven out of nine cases with normal readings. 'This simply confirms the work of other investigators and leads us to assume that the presence of albumin itself increases enzymic activity or in the process of its excretion causes more enzyme to be given to the urine. Allowance must always be made for this factor in estimating the " $\mathrm{d}$ " value in nephritic urine.

44. Braunsehweig: Dissertation, Leipsic, 1910.

45. Wohlgemuth, J.: Biochem. Ztschr., 1909, xxi, 447. 
5. As a test for renal function in nephritis the readings for " $\mathrm{d}$ " agree remarkably well with those of the phthalein test, if we adopt a definite normal limit for both tests, namely, 50 per cent. for the latter and "d" = 8 for the former. The adoption of 50 per cent. as low normal limit for the phthalein test is one which I think is pretty well accepted by most clinical observers.

6. The degrees of impairment as indicated by percentages in phthalein readings and graded dilutions in the " $\mathrm{d}$ " estimation, do not permit comparison. 'This could hardly be expected.

7. Cardiac cases with symptoms of decompensation do not show lowered " $d$ " values for urine, while the phthalein test is usually subnormal. The normal " $d$ " reading in these cases is probably due to albumin or blood or both.

8. Final conclusions as to the relative merits of these two tests, both as to the diagnosis and prognosis, must await the results obtained from a larger number of cases. Meanwhile I would urge that the " $\mathrm{d}$ " test be given an exhaustive trial with relation not only to the phenolsulphonephthalein test, but also to other tests of renal function.

My cordial thanks are due to Drs. Janeway and Longeope for many valuable suggestions, and to the members of the house staff for their cooperation during the course of this work.

437 West Fifty-Ninth Street. 